\title{
A NOTE ON NAMES
}

My use of the ethnonym Eskimo is carefully chosen. In Canada Inuit has largely replaced Eskimo. If applied to all Eskimo peoples across the Arctic, as it often is, the term Inuit is inexact. For example, in Greenland the natives refer to themselves as Greenlanders or Kalaallit; in western arctic Canada they refer to themselves as Inuvialuit. In Alaska, however, Eskimo is commonly used as a broad reference to include the Iñupiat (adjective: Iñupiaq) of northern and western Alaska, as well as the Siberian Yupik of St. Lawrence Island and a few settlements on the coast of the Chukchi Peninsula, the Yup'ik [sic] of southwestern Alaska, and the Alutiiq (Sugpiaq) of the Pacific coast. For discussions of Eskimo synonymy see Goddard (1984, 5-7), Kaplan (1999), and Carpenter (1997, 310).

Russian names and words in the text have been transliterated using a slightly modified version of the standard Library of Congress system, simplifying some vowels and making certain combinations more accessible and easier to pronounce for the nonspecialist. Exceptions have been made for familiar names and phrases: for example, Cape Dezhnev, Koryak, and Tsar Peter. 
This page intentionally left blank 